\title{
PHYTOCHEMICAL EVALUATION AND ANTIMICROBIAL ACTIVITY OF GRACILARIA OPUNTIA: AN IMPORTANT ANTI-DIABETIC RED MARINE MACROALGAE
}

\author{
LAVANYA RAYAPUa, FAZINA MAKKAR ${ }^{\mathrm{b}}$, KAJAL CHAKRABORTY ${ }^{\mathrm{b}}$, LOKANATHA VALLURU ${ }^{\mathrm{a}}$ \\ aDepartment of Biotechnology, Dravidian University, Kuppam 517426, AP, India, bCentral Marine Fisheries Research Institute (CMFRI), \\ Cochin 682001, Kerala, India \\ Email: lokanath.valluru@gmail.com
}

Received: 19 Aug 2017, Revised and Accepted: 13 Oct 2017

\section{ABSTRACT}

Objective: Microorganisms have developed resistance to existing available antibiotics, thereby thriving to anemerging need for new generation of antibiotics. Since seaweeds provide a rich source of bioactive molecules, the present study aimed to investigate its anti-microbial potential against clinically important microorganism.

Methods: Red sea weed namely Gracilaria opuntia collected from different coastal regions of Gulf of Mannar and Rameswaram, India was used. For microbiological testing of the seaweed extracts, agar disc diffusion method was used.

Results: The zone of inhibition was measured for all the different crude algal extracts against strains of microorganisms such as Escherichia coli, Staphylococcus aureus, Klebsiella pneumonia and Pseudomonasputida that cause diseases in diabetic patients. Crude extracts prepared from aqueous, ethanol and methanol extraction procedures revealed that aqueous extraction procedure have a wide range of antimicrobial activity against all thetest pathogens.

Conclusion: The overall antibacterial activity assessed from the above results indicates the presence of active constituents in the extractions of seaweeds which can be explored for the production of significant molecules which could be used in pharmaceutical industry.

Keywords: Gracilariaopuntia, Antimicrobial activity, Agar diffusion method, Solvent extracts

(C) 2017 The Authors. Published by Innovare Academic Sciences Pvt Ltd. This is an open access article under the CC BY license (http://creativecommons.org/licenses/by/4.0/] DOI: http://dx.doi.org/10.22159/ijcpr.2017v9i6.23426

\section{INTRODUCTION}

The sea, covering $70 \%$ of the Earth's surface, offers a considerably broader spectrum of biological diversity than terra firma. Containing approximately $75 \%$ of all living organisms, the marine environment offers a rich source of natural products with the potential therapeutic application [1]. A report suggests that marine organisms are source material for structurally unique natural products with pharmacological and biological activities [2-4].

Among the marine organisms, the macroalgae (seaweeds) occupy an important place as a source of biomedical compounds [5-6]. Seaweeds are the eukaryotic organism that lives in salty water in the ocean and it is found to be a potential source of bioactive natural products [7]. They contain compounds including sterols, terpenoids, phenolic compounds which show bioactive against microorganisms.

In recent years, there are numerous reports of macro algae-derived compounds that have a broad range of biological activities such as antibacterial, antifungal, antiviral, antineoplastic, antidiabetic, antiinflammatory, anti-tumoric, cytotoxic and antimitotic activities [8-9]. About 2400 natural products have been isolated from macroalgae belonging to the classes Rhodophyceae, Phaeophyceae and Chlorophyceae [10]. Presently seaweeds constitute commercially important marine renewable resources which are providing valuable ideas for the development of new drugs against diabetes, microbial infections and inflammations [11]. Algal constituents include acids, alkaloids, amines, antibacterial, antifungal, antiviral substances, lipids, sterols, steroids, fatty acids, phenolic compounds, phytochromes, pigments, proteins, peptides, amino acids, sugar, alcohols and vitamins. Gracilaria opuntia belongs to the family Rhodophyceae (Red algae). These are highly evolved multicellular forms with well-developed branched thalli. Except for few species, they are exclusively marine and vary in size and shape. They are epiphytes, growing as a crust on the rocks or shells as a large fleshy, branched or blade-like thalli. The thallus is basically filamentous, simple or branched, free or compacted to form pseudoparenchyma with uni or multiaxial construction. They inhabit intertidal to subtidal zones of coastal areas [12].

The present study was aimed to study the phytochemical screening and antimicrobial activity of Gracilaria opuntia solvent extracts against pathogenic bacteria.

\section{MATERIALS AND METHODS \\ Collection of marine algae samples}

The identities of the red marine macroalgae Gracillaria opuntia considered in the present study were ascertained with the sample specimens maintained in the Marine Biodiversity Museum of Central Marine Fisheries Research Institute. The marine macroalgae were collected freshly from the Gulf of Mannar in Mandapam region located between $8^{\circ} 48^{\prime} \mathrm{N}, 78^{\circ} 9^{\prime} \mathrm{E}$ and $9^{\circ} 14^{\prime} \mathrm{N}, 79^{\circ} 14^{\prime} \mathrm{E}$ on the south-east coast of India during the months spanning between August-April. Samples collected $(2 \mathrm{~kg})$ were washed in running water and shade dried before being pulverized to a minimum particle size.

\section{Preparation of marine macroalgae extracts}

The powdered marine macroalgae samples $(1000 \mathrm{~g})$ were extracted with $n$-hexane $(600 \mathrm{ml} \times 2)$, at room temperature for $24 \mathrm{~h}$, and the pigments were separated. The residue was filtered through Whatman No.1 filter paper and extracted three times with methanol $(\mathrm{MeOH})$ and ethanol (EtOH) $\left(50-60{ }^{\circ} \mathrm{C}, 3 \mathrm{~h}\right)$, respectively, filtered through Whatman No. 1 filter paper, and the obtained filtrate was concentrated at $50{ }^{\circ} \mathrm{C}$ in rotary vacuum evaporator (Heidolf, Germany) to get the dark brown viscous mass of $\mathrm{MeOH}(112 \mathrm{~g})$ and EtOH fractions (96 g), respectively. The aqueous extracts of the seaweed were prepared by extracting the dried marine macroalgae powder (500 g) with $80-90{ }^{\circ} \mathrm{C}$ hot water for $3-4 \mathrm{~h}$. The contents were thereafter cooled $\left(4^{\circ} \mathrm{C}\right)$ and centrifuged at $8500 \mathrm{rpm}$ for 15 min (Sorvell Biofuge Stratos, Thermo Scientific, USA) to remove the solid residues that were freeze-dried to get the crude aqueous extract ( $27 \mathrm{~g}$ ). The aqueous extract of $G$. opuntia was concentrated 
before precipitated with alcohol $(500 \mathrm{ml})$. The precipitate was lyophilized to get a dried oligosaccharide fraction of $G$. opuntia. This was then powdered and packed in vacuum packed bags and stored in the refrigerator until further use.

\section{Phytochemical screening}

Phytochemical analysis of all the evaporated solvent extracts was conducted following the procedure of Indian pharmacopoeia [13].

\section{Test for alkaloids}

$200 \mathrm{mg}$ of plant material was dissolved in $10 \mathrm{ml}$ of methanol and filtered. For $2 \mathrm{ml}$ filtrate and $1 \% \mathrm{HCl}+$ steam, $1 \mathrm{ml}$ filtrate +6 drops Mayer's reagent/Wagner's reagent/Dragendorff's reagent was added. Creamish precipitate/brownish red precipitate/orange precipitate indicated the presence of respective alkaloids.

\section{Test for tannins}

$200 \mathrm{mg}$ of plant material was dissolved in $10 \mathrm{ml}$ of distilled water and filtered. For $2 \mathrm{ml}$ filtrate $+2 \mathrm{ml} \mathrm{FeCl}_{3}$ was added. Blue/black precipitate indicated the presence of tannins.

\section{Test for flavonoids}

$200 \mathrm{mg}$ of plant material was dissolved in $10 \mathrm{ml}$ of ethanol and filtered. For $2 \mathrm{ml}$ filtrate+conc. $\mathrm{HCl}+$ magnesium was added. Ribbon pink/tomato red color indicated the presence of flavonoids.

\section{Test for steroids (Liebermann-burchard reaction)}

$200 \mathrm{mg}$ of plant material was dissolved in $10 \mathrm{ml}$ of chloroform and filtered. For $2 \mathrm{ml}$ of filtrate $+2 \mathrm{ml}$ of acetic anhydride $+\mathrm{H}_{2} \mathrm{SO}_{4}$ was added. Blue/greenring indicated the presence of steroids.

\section{Test for phenols}

$1 \mathrm{ml}$ of each solvent extracts dissolved in alcohol/water was separately treated with $1 \mathrm{ml}$ of neutral $\mathrm{FeCl}_{3}$. The change in colour indicated the presence of phenols.

\section{Test for sugars}

The extract ( $100 \mathrm{mg}$ ) was dissolved in $5 \mathrm{ml}$ of water and filtered. To 2 $\mathrm{ml}$ of filtrate, two drops of an alcoholic solution of $\alpha$-naphthol were added, the mixture was shaken well and $1 \mathrm{ml}$ of concentrated sulphuric acid was added slowly along the sides of the test tube and allowed to stand. Violet rings indicate the presence of carbohydrates.

\section{Test for saponins}

The extract ( $50 \mathrm{mg}$ ) was diluted with distilled water and made up to $20 \mathrm{ml}$. The suspension was shaken in a graduated cylinder for 15 $\min$. A $2 \mathrm{~cm}$ layer of foam indicates the presence of Saponins.

\section{Antimicrobial screening}

\section{Laboratory test organisms and their cultural conditions}

The test bacterial strains used for the study were Escherichia coli (ATCC 9837, Gram-negative), Staphyloccocusaureus (ATCC 6538, Gram-positive), Klebsiellapnemoniae (ATCC 1705, Gram-negative) and Pseudomonasputida (ATCC 12633, Gram-negative). Specific growth conditions were maintained. The bacteria used for the study were procured from ATCC. All the cultures were maintained at $4{ }^{\circ} \mathrm{C}$ in nutrient agar slants.

\section{Preparation of inoculums}

A loop full of the test culture was taken from respective strains of agar slants and subcultured in fresh tubes containing nutrient broth and incubated for overnight at $37^{\circ} \mathrm{C}$. The obtained cultures were centrifuged at $5000 \mathrm{rpm}$ for $15 \mathrm{~min}$. Bacterial suspension was added to fresh media which gives a final concentration of $107 \mathrm{cfu} / \mathrm{ml}$ [14].

\section{Antibacterial activity assay}

The antibacterial activity was tested by agar well diffusion method [15] as adopted earlier and with little modifications was used [16]. Seeded agar was made using nutrient agar medium. After the medium preparation, it was sterilized and allowed to cool so that the medium gets solidified. Just before solidification $0.1 \mathrm{ml}$ of diluted inoculum $(105 \mathrm{cfu} / \mathrm{ml})$ of test organism was added to the medium and then it was poured into the sterilized petri dishes under aseptic conditions. Under sterile conditions, wells of $4 \mathrm{~mm}$ diameter were punched into the agar medium with the help of sterile cork borer. These wells were filled with $10,25,50,75$ and $100 \mu$ l of algae extract and of $500 \mu \mathrm{g} / \mathrm{ml}$ concentration and solvent Dimethyl sulphoxylate (DMSO) as a control. The plates were incubated at $37^{\circ} \mathrm{C}$ for $24 \mathrm{~h}$. The antibacterial activity was evaluated by measuring the zone of inhibition (in $\mathrm{mm}$ ) against test organisms. The antibiotics ampicillin, tetracycline and erythromycin at $500 \mu \mathrm{g} / \mathrm{ml}$ concentration each were used as positive controls.

\section{RESULTS AND DISCUSSION}

\section{Phytochemical analysis}

Preliminary investigation of phytochemical analysis of selected crude extracts revealed the presence of various compounds such as alkaloids, flavonoids, phenols, saponins, steroids, sugars and tannins. Alkaloids, flavonoids detected in the extracts are compounds that have been documented to possess a variety of medicinal properties and health-promoting effects. Phenolics are the largest group of phytochemicals have been said to account for most of the antioxidant activity of algae extract. These classes (such as alkaloids, flavonoids, phenols, saponins, steroids, sugars and tannins) of compounds are known to have curative activity against several pathogens and therefore could suggest the use traditionally for the treatment of various illnesses [17]. From the results depicted in table 1 higher concentration of alkaloids were present in aqueous extract and maximum concentrations of flavonoids were present in aqueous compared to ethanol and methanol extracts. Higher concentration of phenols was recorded in ethanol and methanol extracts when compared to aqueous extracts. The moderate concentration of saponins was observed in aqueous, ethanol and methanol extracts of $G$. opuntia. The three extracts don't shows any steroid. High-level sugars were present in the aqueous, ethanol and methanol extracts. Moderate concentrations of tannins were present in aqueous and methanol extracts compared to ethanol extracts. The most of the phytochemicals classified as secondary metabolites are produce from algae, often their function unknown, but certain phytochemicals have structural, functional and general defence against pathogens so the preliminary phytochemical studies received pronounced importance, because the crude drugs posses varied composition of secondary metabolites [18]. Considering the high economical and pharmacological importance of secondary metabolites, industries are deeply interested in the large-scale production of algal substances [19-20].

\section{Anti-microbial activity}

Seaweeds are the eukaryotic organisms that live in salty water in the ocean and is recognized as a potential source of bioactive natural products [7]. They contain compounds ranging from sterols, terpenoids, phenols which may help to enhance the antimicrobial activity of red marine algae [8]. In the present study, the antibacterial activity of three different solvents viz., aqueous, methanol and ethanol extracts of Gracilaria opuntia was evaluated against pathogenic bacteria. Among three solvent extracts tested, the aqueous extract showed the greatest inhibition diameters against gram positive and gram negative bacterial isolates (fig. 1 and 2 and table. 2). The similar results were observed G. folifera and G. carrasa [21, 22]. The results from the present study showed that the gram-positive bacteria are more susceptible than gram negative bacteria on seaweed extracts which was also supported from earlier works with different species of seaweeds indicating that the more susceptibility of gram-positive bacteria to the algal extracts was due to the differences intheir cell wall structure and their composition [23].

The aqueous methanol and ethanol extract of Gracilaria opuntia at a different concentration such as $10,25,50,75$ and $100 \mu \mathrm{g} / \mathrm{ml}$ showed a zone of inhibition. Among them, the aqueous extract has showed the highest zone of inhibition ( $4.8 \mathrm{~mm}$ )against the $E$. coli followed by Pseudomonas putida $(4.6 \mathrm{~mm})$, Klebsiella pneumonia $(4.5 \mathrm{~mm})$, and Staphylococcusaureus $(4.0 \mathrm{~mm})$ at $100 \mu \mathrm{g} / \mathrm{ml}$ concentration. The minimum zone of inhibition was recordedin methanol and ethanol 
extract of Gracilaria opuntia against E. coli $(3.5$ and $3 \mathrm{~mm}$ ) followed by Pseudomonas putida (2.5 and $2.3 \mathrm{~mm}$ ), Klebsiellapneumonia ( 4.3 and $3.5 \mathrm{~mm}$ ), and Staphylococcusaureus (3.5 and $1.5 \mathrm{~mm}$ ).

The zone of inhibition obtained from the aqueous extract of seaweed Gracilaria opuntia against bacterial pathogens was comparatively very high when compared to the methanolic and ethanolic solvent extracts. No zone of inhibition was seen in DMSO control and the positive control ampicillin, tetracycline and erythromycin showed a zone of inhibition ranging from $6.0 \mathrm{~mm}$ to $8.2 \mathrm{~mm}$ against the test bacterial pathogens (fig. 3).
Invariably, seaweeds have been proven to be a potent source of antimicrobial compounds. Aqueous extract of Gracilaria opuntia belongs to Rhodophyta exhibited broad-spectrum antibacterial activity [24].

Previously it has been reported in some of the marine macoalgae extracts such as Enteropmorphacompressa, Cladophorosiszoolingeri, Padinagymnospora, Sargassumwightii and Gracilariacorticata were active against gram positive and gram negative bacteria [25]. Based on the present findings, it could be inferred that the bioassay-guided fractionation and purification may come up with potent antibacterial compounds.
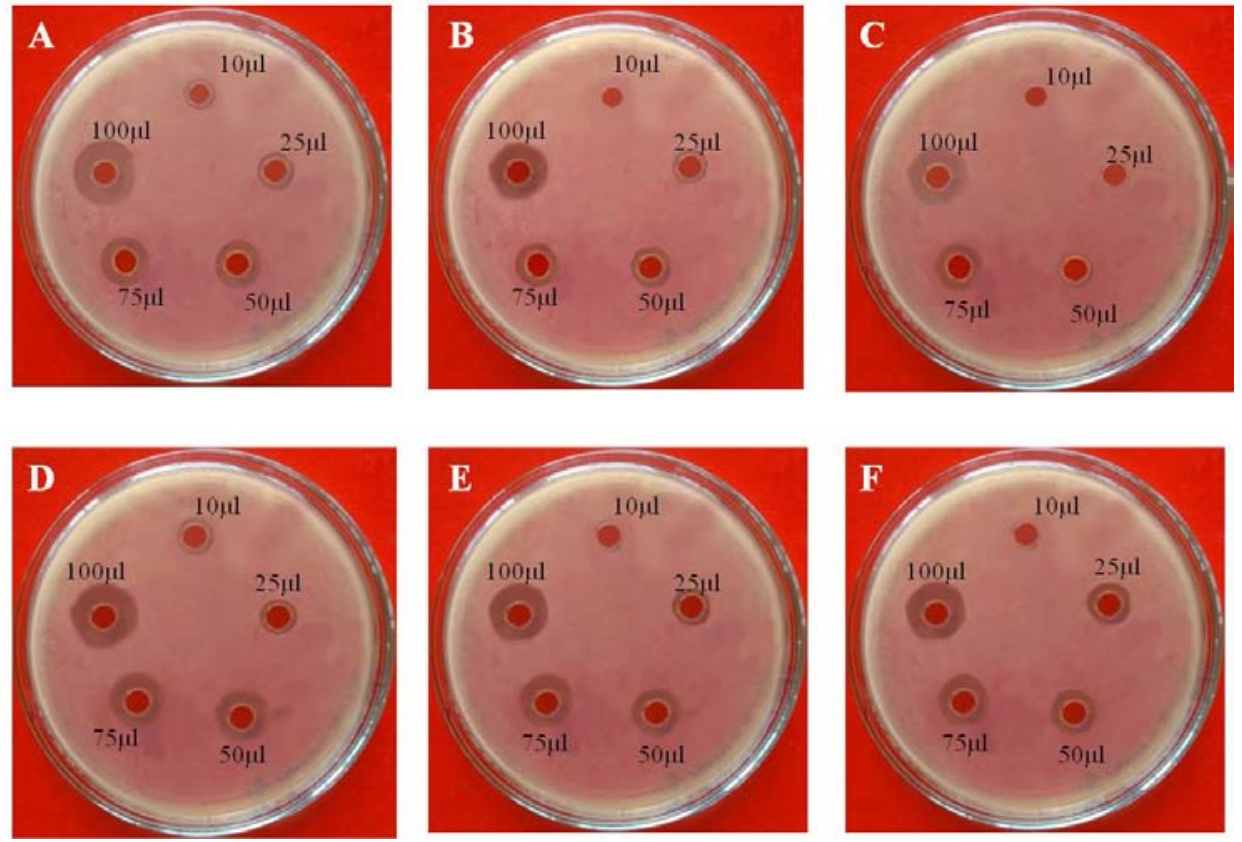

Fig. 1: Antibacterial activity of aqueous (A, D), ethanol (B, E) and methanol (C, F) extracts of marine macro algae-Gracilaria opuntia against Escherichia coli (A, B, C) and Klebsiellapneumonia (D, E, F). Upon treating with G. opuntia at different concentrations the antimicrobial activity is reduced. $100 \mu \mathrm{l}$ has shown a significant zone of inhibition
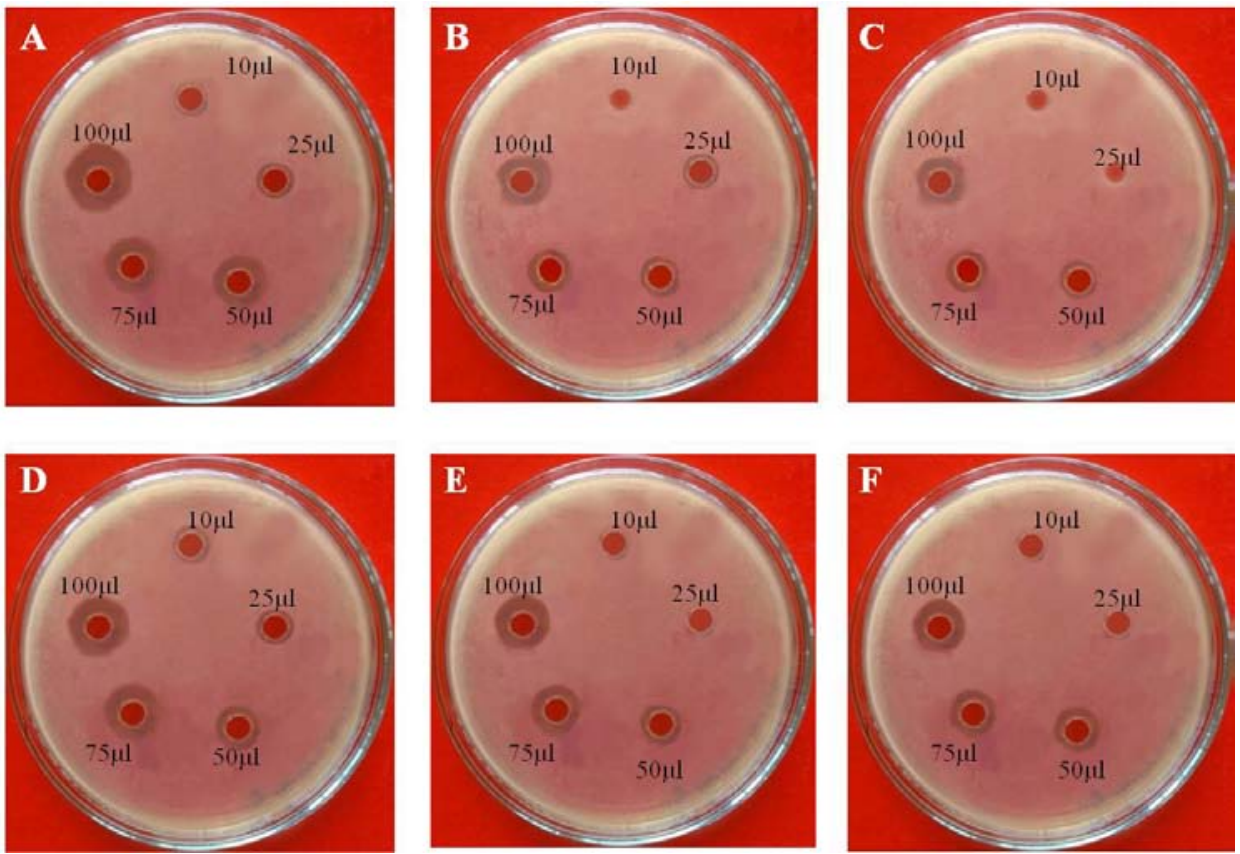

Fig. 2: Antibacterial activity of aqueous (A, D), ethanol (B, E) and methanol (C, F) extracts of marine macro algae-Gracilaria opuntia against Pseudomonas putida (A, B, C) and Staphylococcus aureus (D, E, F). Upon treating with FM4 at different concentrations the antimicrobial activity is reduced. $100 \mu \mathrm{l}$ has shown a significant zone of inhibition 

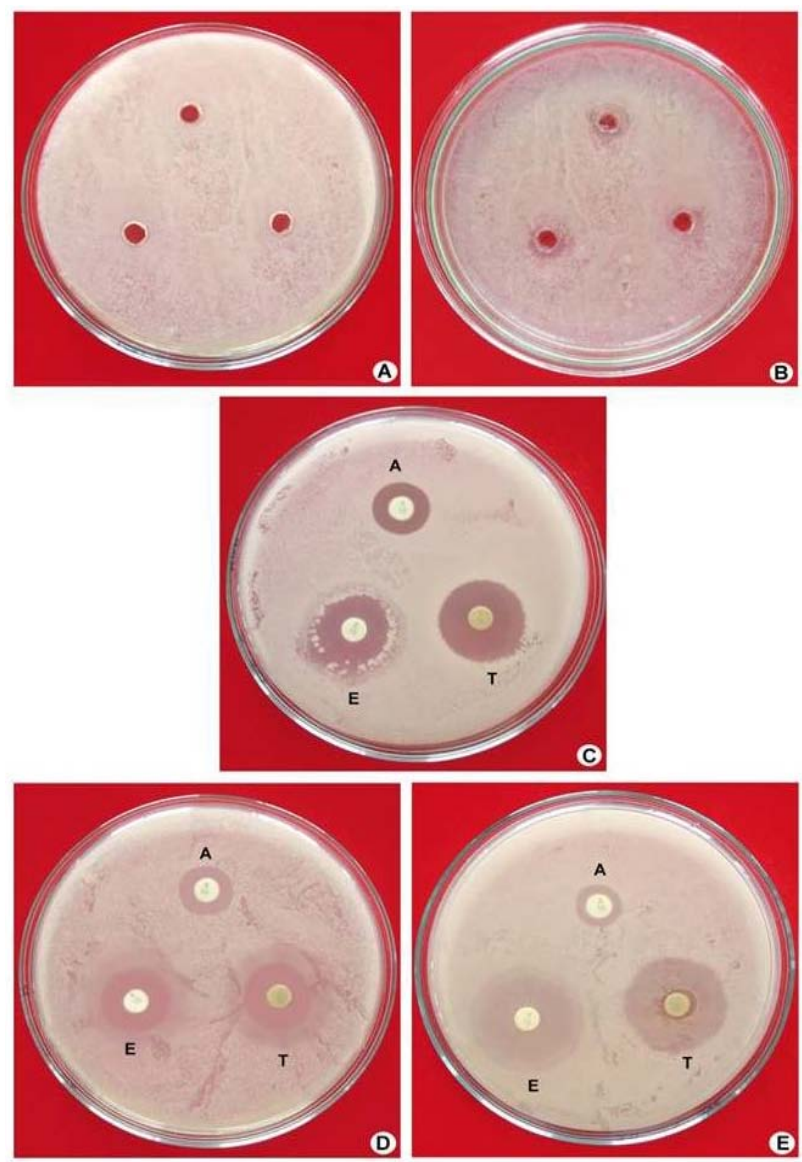

Fig. 3: A-B) DMSO used as a negative control to test the activity against Pseudomonas putida and Staphylococcus aureus. C-E) Commercial antibiotics such as tetracycline (T), ampicillin (A) and erythromycin (E) used as a positive control against E. coli, S. aureus and P. putida

Table 1: Phytochemical analysis of secondary metabolites such as alkaloids, flavonoids, phenols, saponins, steroids, sugars and tannins in Gracilaria opuntia

\begin{tabular}{llll}
\hline Type of secondary metabolites & Aqueous extract & Methanolic extract \\
\hline Alkaloids & ++ & + & Ethanolic extract \\
Flavonoids & ++ & + & + \\
Phenols & - & + & + \\
Saponins & + & + & + \\
Steroids & - & ++ \\
Sugars & ++ & + & + \\
Tannins & + & + & + \\
\hline
\end{tabular}

Table 2: Antimicrobial activity of aqueous, ethanolic and methanolic extracts of marine macroalgae Gracilaria opuntia. Among the three extracts, aqueous extract has shown significant and maximum zone of inhibition compared to ethanolic and methanolic extracts treated groups

\begin{tabular}{|c|c|c|c|c|c|c|c|c|c|c|c|c|c|c|c|c|}
\hline \multirow[t]{2}{*}{$\begin{array}{l}\text { S. } \\
\text { No. }\end{array}$} & \multirow{2}{*}{$\begin{array}{l}\text { EXTRACTS- } \mu \text { l } \\
\text { micro } \\
\text { organisms }\end{array}$} & \multicolumn{5}{|c|}{$\begin{array}{l}\text { Gracilariaopuntia (Aqueous) (Zone } \\
\text { of inhibition in } \mathrm{mm} \text { ) }\end{array}$} & \multicolumn{5}{|c|}{$\begin{array}{l}\text { Gracilariaopuntia (Ethanol) (Zone } \\
\text { of inhibition in } \mathrm{mm} \text { ) }\end{array}$} & \multicolumn{5}{|c|}{$\begin{array}{l}\text { Gracilariaopuntia (Methanol) } \\
\text { (Zone of inhibition in } \mathrm{mm} \text { ) }\end{array}$} \\
\hline & & 10 & 25 & 50 & 75 & 100 & 10 & 25 & 50 & 75 & 100 & 10 & 25 & 50 & 75 & 100 \\
\hline 1 & Escherichia coli & 1.2 & 2.0 & 2.7 & 3.0 & 4.8 & - & 1.5 & 2.2 & 2.8 & 3.5 & - & - & 0.5 & 1.5 & 3 \\
\hline 2 & $\begin{array}{l}\text { Klebsiella } \\
\text { pneumonia }\end{array}$ & 0.5 & 1.0 & 1.8 & 2.5 & 4.5 & - & 0.5 & 1.0 & 2.0 & 4.3 & - & 1.5 & 1.5 & 2.0 & 3.5 \\
\hline 3 & $\begin{array}{l}\text { Pseudomonas } \\
\text { putida }\end{array}$ & 0.5 & 1.0 & 2.0 & 2.0 & 4.6 & - & 0.5 & 0.5 & 1.0 & 2.5 & - & - & 1.0 & 1.5 & 2.3 \\
\hline 4 & $\begin{array}{l}\text { Staphylococcus } \\
\text { aureus }\end{array}$ & 0.5 & 1.0 & 1.5 & 3.0 & 4.0 & - & - & 1.0 & 2.0 & 3.5 & - & - & 0.9 & 1.1 & 1.5 \\
\hline
\end{tabular}

\section{CONCLUSION}

The present research concluded that the organic solvent extraction was suitable to verify the antimicrobial properties of Gracilaria opuntia and they supported by many investigations. The investigation on antimicrobial activity of extracts of Gracilaria opuntia showed that the aqueous extract shows promising antimicrobial activity when compared to other solvent extracts. The results also indicated that scientific studies carried out on seaweed extracts having traditional claims of effectiveness might warrant 
fruitful results. G. opuntia could serve as a useful source of new antimicrobial agents. The present study justifies the claimed uses of G. opuntia in the traditional system of medicine to treat various infectious diseases caused by the microbes. These results suggest the possibility of using marine algae extracts in therapy as natural alternatives to antibiotics currently in the market, and clearly show that seaweeds are a valuable source of biologically active compounds. Further research is underway to determine the structure and nature of these antibacterial substances.

\section{ACKNOWLEDGEMENT}

Dr. Lokanatha Valluru is highly thankful to DST-Science and Engineering Research Board (No. SR/S1/OC-96B/2013 Dt. 20.11.2013). The government of India, New Delhi, for providing financial assistance in the form of a research grant.

\section{CONFLICTS OF INTERESTS}

Authors declare no conflicts of interest

\section{REFERENCES}

1. DeVries DJ, Beart PM. Fishing for drugs from the sea: status and strategies. Trends Pharmacol Sci 1995;16:275-9.

2. Faulkner DJ. Marine natural products. Nat Prod Rep 2001;18:1-49.

3. Da Rocha AB. Natural products in anticancer therapy. Curr Opin Pharmacol 2001;1:364-9.

4. Schwartsmann G. Marine organisms as a source of anticancer agents. Lancet Oncol 2001;2:221-5.

5. Manilal A. Bioactivity of the red alga Asparagopsistaxiformis collected from the south-western coast of India. Brazilian J Oceonography 2010;58:93-100.

6. Selvin J, Lipton AP. Biopotentials of Ulvafasciata and Hypneamusciformis collected from the peninsular coast of India. J Mar Sci Tech 2004;12:1-6.

7. Michael TM, John MM, Jack P. Brock microbiology of microorganisms. $11^{\text {th }}$ ed. New Jersey; 2005.

8. Perry NB. Cytotoxic and antifungal 1,4-naphthoquinone and related compounds from a New Zealand brown algae Landsburgiaquercifolia. J Nat Prod 1991;54:978-85.

9. Harada H. Selective antitumor activity in vitro from marine algae from Japan coasts. Biol Pharm Bull 1997;20:541-6.

10. Elena M. Mailiohydrin, a cytotoxic chamigrene dibromohydrin from a phillippine Laurencia species. J Nat Prod 2003;64:790-1.
11. Bhagavathy S, Sumathi P, Bell IJB. Green algae chlorococcumhumicola-a new source of bioactive compounds with antimicrobial activity. Asian Pacific J Trop Biomed 2011;1:S1-S7.

12. Gur S, Turgut-Balik D, Gur N. Antimicrobial activities and some fatty acids of turmeric, ginger root and linseed used in the treatment of infectious diseases. World J Agric Sci 2006;2:439-42.

13. Perez C, Pauli M, Bazerque P. An antibiotic assay by agar well diffusion method. Acta Biol Med Exp 1990;15:113-5.

14. Ahmad I, Beg AZ. Antimicrobial and phytochemical studies on 45 Indian medicinal plants against multi-drug resistant human pathogens. J Ethnopharmacol 2001;74:113-23.

15. Indian Pharmacopeia 3(II), Government of India, Ministry of Health, Controller of Publications. New Delhi, India; 1985.

16. Usman H, Osuji JC. Phytochemical and in vitro antimicrobial assay of the leaf extract of newbouldia leavis. Afr J Tradit Complementary Altern Med 2007;4:476-80.

17. Mao SC, Guo YW. Sesquiterpenes from chinese red algae Laurenciaokamurai. Chinees J Natl Med 2010;8:321-5.

18. Plaza M, Santoyo S, Jaime L. Screening for bioactive compounds from alga. J Pharm Biomed Anal 2010;51:450-5.

19. Michael TM, John MM, Jack P. Brock microbiology of microorganisms. 11th ed. New Jersey; 2005.

20. Perry NB, Blunt JW, Munro MH. Cytotoxic and antifungal 1,4naphthoquinone and related compounds from a New Zealand brown algae. Landsburgiaquercifolia. J Natl Prod 1991;54:978-85.

21. Kolanjinathan K, Ganesh P, Saranraj P, Sekar D. Antimicrobial activity of Gracilariafoliferaextracts against pathogenic microorganisms. Int J Curr Biochem Biotechnol 2012;2:6-9.

22. Prabhahar C, Saleshrani K, Tharmaraj K, Saranraj P. Investigation on antimicrobial activity of Gracilariacrassa extracts against pathogenic microorganisms. Int J Recent Sci Res 2012;3:166-71.

23. Taskin E, M Ozturk, Taskin E, Kurt. Antibacterial activities of some marine algae from the Aegean sea (Turkey). Afr J Biotechnol 2007;6:2746-51.

24. Kandhasamy M, Arunachalam KD. Evaluation of in vitro antibacterial property of seaweeds of the southeast coast of India. Afr J Biotechnol 2008;7:1958-61.

25. De-Campos TGM, Diu MBS, Koening ML, Periera EC. Screening of marine algae from Brazilian Northeastern coast for antimicrobial activity. Marine 1988;31:375-7. 